\title{
Early Snowmelt Enhances the Carbon Sequestration of Hummock-Forming Sphagnum Mosses on Boreal Wetlands
}

\author{
Niko Silvan ${ }^{*}$, Kari Jokinen² \\ ${ }^{1}$ Natural Resources Institute Finland, Natural Resources and Bioproduction, Parkano Unit, Parkano, Finland \\ ${ }^{2}$ Natural Resources Institute Finland, Natural Resources and Bioproduction, Viikki Unit, Helsinki, Finland \\ Email: "niko.silvan@luke.fi
}

Received 16 September 2015; accepted 12 February 2016; published 15 February 2016

Copyright (C) 2016 by authors and Scientific Research Publishing Inc.

This work is licensed under the Creative Commons Attribution International License (CC BY). http://creativecommons.org/licenses/by/4.0/

(c) 7 Open Access

\section{Abstract}

Sphagnum mosses are globally important owing to their considerable peat-forming ability and their potential impact on global climatic cycles acting as a long-term net carbon sink. However, changes in climatic conditions due to global warming may affect the relations between Sphagnum mosses and vascular plants but also the competition among Sphagnum, and thus alter the accumulation of carbon on boreal wetlands. Sphagnum mosses are a plant genus with a favorable ability to grow in low solar irradiance and temperature conditions compared to vascular plants. This may be increasingly beneficial in increased wintertime temperatures and predated snowmelt conditions. To understand particularly the importance of early spring photosynthetic activity and thus the role of the length of growing season on carbon balance, we analyzed the $\mathrm{CO}_{2}$ exchange of Sphagnum mosses with closed chamber technique in two categories of microtopographical habitats, hummocks and lawns, during four seasons 2010-2013 on a raised bog in Central Finland. During $\mathrm{CO}_{2}$ exchange measurements, instantaneous net ecosystem exchange (NEE) and ecosystem respiration (RE) were measured. Our results show that the mean measured seasonal NEE, i.e. the instantaneous net carbon sequestration, of hummocks was generally only slightly higher than the NEE of lawns, but the mean measured seasonal RE of hummocks was clearly and significantly higher than the RE of lawns in every study year. A reason for the observed still higher seasonal carbon sequestration of hummocks than that of lawns besides the slightly higher rate of carbon accumulation was the longer duration of physiologically active growing season. Therefore, hummock-forming Sphagnum mosses exposed firstly from snow cover showed to get the extra time for photosynthesis and thus extra benefit compared to other mire plants. This may be further enhanced by the expansion of hummock-forming Sphagnum moss dominated raised bogs towards northern aapa-mire region due to the global warming.

\footnotetext{
${ }^{*}$ Corresponding author.
} 
Keywords

Sphagnum Mosses, Boreal Wetlands, Mire Microtopography, Carbon Dynamics, Global Warming

\section{Introduction}

Sphagnum moss species are globally important owing to their considerable peat-forming ability and their potential impact on global climatic cycles [1] [2]. Sphagnum is the most important peat forming plant genus and there may be more carbon stored in Sphagnum than in any other genus [3]. The genus Sphagnum includes 250 - 450 species, but rather fewer than 50 species contribute to peat formation on a large scale [4]. These peat-producing species are most abundant on boreal wetlands above latitude 45N [5]. Thus, Sphagnum forms a major component of boreal wetlands, which cover $2 \%$ of the total land area [6]. These wetlands have acted as a long-term net carbon sink and take up $0.07 \mathrm{Pg}$ carbon per year [1] [7], equivalent to $5 \%$ of the total net carbon flux from atmosphere to land [6]. Sphagnum mosses solely have thus been responsible for the sequestration of large quantities of carbon and play an important role in the global carbon cycle [8].

Changes in climatic conditions due to the global warming may affect the relations between Sphagnum mosses and vascular plants [9]. Changes in climatic conditions may also affect competition among Sphagnum, both through direct moisture changes and through the effects on Sphagnum density and growth rate [10] [11]. These may have important consequences for the long-term stability of the mire vegetation community [12]. On boreal wetlands, vascular plant performance is further controlled by the presence of Sphagnum, which often dominates the bottom layer and the peat deposits in which the plants grow [3]. Sphagnum mosses strongly reduce the availability of nutrients to vascular plants on nutrient-poor mires by efficiently accumulating nutrients from atmospheric deposition and reducing decay and mineralization rates [9] [13]-[15]. At the same time, however, they force vascular plants to keep pace with their progressively increasing height, in order not to become buried [9] [10] [16]. Therefore global warming may impact on the functioning of mire ecosystems via alterations in species composition, and thus alter also the accumulation of carbon on boreal wetlands [8] [12] [17].

According to the six-year study of Aurela et al. [18] on a subarctic fen in northern Finland, the interannual variation of the $\mathrm{CO}_{2}$ balances originates almost completely from the variations during the snow-free period. In their study, the snowmelt timing was proven to be the most important single determinant of the annual carbon balance. In contrast to a commonly-held view, the hydrometeorological conditions during the growing season had only a minor effect on the annual balance, emphasizing the importance of the start of the growing season [18]. Sphagnum mosses have a favorable ability to grow in low solar irradiance and temperature conditions compared to vascular plants [19] [20]. In the study of Harley et al. [19], the photosynthesis of Sphagnum angustifolium saturated already in the photosynthetic photon flux density (PPFD) under $500 \mu \mathrm{mol} \cdot \mathrm{m}^{-2} \cdot \mathrm{s}^{-1}$. Photosynthesis started at ca. $\pm 0^{\circ} \mathrm{C}$, when photosynthetic rates at $5^{\circ} \mathrm{C}$ were already ca. $50 \%$ of maximum and the saturation temperature was at ca. $10^{\circ} \mathrm{C}$ [19]. These requirements would normally be met already in late March at least in southern and middle boreal region assuming that no snow cover occurs.

Boreal raised bogs show a typical pattern of microtopographical habitats, ranging from relatively dry but regularly (in spring after snowmelt) inundated lawns to dry high hummocks (without inundation period), with a different set of Sphagnum species occupying each microhabitat [21]. Therefore the decrease in snow cover in early spring might be more beneficial for hummock-forming Sphagnum species than for lawn species. This could enhance the expansion of hummock dominated raised bogs towards northern aapa-mire region due to the global warming.

We hypothesized therefore 1) that productivity of lawn species (e.g. S. fallax and S. balticum) will not increase with decreasing snow cover, whereas biomass production of hummock species (e.g. S. fuscum and $S$. magellanicum) will increase, and 2) that global climate warming with shortened snow cover period may thus promote rather than threaten the carbon sequestration ability of boreal wetlands by favoring the growth of hummock-forming Sphagnum.

\section{Materials and Methods}

\subsection{Study Site}

The study was carried out during $2010-2013$ on a pristine raised bog at Kauhaneva, central Finland $\left(62^{\circ} 13^{\prime} \mathrm{N}\right.$, 
$22^{\circ} 26^{\prime} \mathrm{E}$ ). The mire site type of the study site was low sedge S. papillosum fen with large Sphagnum hummocks [22]. The study site lies in the transitional zone between southern-boreal and middle-boreal coniferous forest zones, on the edge of a large raised bog area with the characteristics of both poor minerotrophy (lawns) and ombrotrophy (hummocks). The long term (1983-2013) annual mean temperature of the site was $3.8^{\circ} \mathrm{C}$, the annual mean precipitation $612 \mathrm{~mm}$ and the accumulative temperature sum $\left(>+5^{\circ} \mathrm{C}\right) 1156$ degree-days.

The surface of the study site consisted of a typical pattern of boreal raised bogs: relatively dry but regularly inundated lawns to dry hummocks. The height of the studied hummocks was ca. $0.4 \mathrm{~m}$ compared to the surrounding lawn area. Soil of the site consisted of weakly decomposed Sphagnum-Carex peat with the depth of ca. 1 meter. Dominant mosses on the hummock-plots were S. fuscum and S. magellanicum, and on the lawn-plots $S$. balticum and S. fallax.

\subsection{Vegetation Monitoring}

A leaf area index (LAI) estimation was employed in order to relate $\mathrm{CO}_{2}$ fluxes to the spatial and temporal variation in vegetation. For vascular plants, species-specific LAIs in each sample plot were estimated in early August during 2010-2013 as a product of the number of leaves and the average leaf size [23]. The number of green leaves of each species was estimated by counting the number of the leaves in permanent sub-sample plots within each sample plot that accounted for $10 \%$ of the total area of the plot.

\section{3. $\mathrm{CO}_{2}$ Exchange Measurements}

Six $\mathrm{CO}_{2}$ exchange measurement plots were established at the site. Three of the measurement plots were established on the hummock surfaces and the other three on the lawn surfaces. $\mathrm{CO}_{2}$ exchange measurement occasions with closed chamber technique [24] were carried out during the whole snow-free period (March/April-October) 2010-2013. The timing of snowmelt was monitored at the site, and $\mathrm{CO}_{2}$ exchange measurements were started in each spring immediately after the snow cover was melt at least from all of the hummock plots.

Prior to measurements, an aluminium collar $(60 \times 60 \mathrm{~cm})$ was permanently inserted into $30 \mathrm{~cm}$ depth in each plot. The collar was surrounded by a water groove that allowed chamber placement and air-tight sealing of the measurement system. Instantaneous net ecosystem $\mathrm{CO}_{2}$ exchange (NEE) in each plot was measured with a transparent plastic chamber and a portable infra-red gas analyzer (EGM-4, PP Systems, UK). Measurements over 90 - $180 \mathrm{~s}$ were carried out in the full light and under an artificial shade reducing the ambient light by $40 \%$ - $60 \%$. During the measurements, the $\mathrm{CO}_{2}$ concentration in the chamber headspace, photo synthetically active radiation (PAR) under the chamber roof, and the chamber temperature were recorded at 15-s intervals. After the measurements in light, the chamber was covered with an opaque hood and the ecosystem respiration (RE) in the dark was measured. Water table level (WTL) in a perforated tube next to each plot, and peat temperatures at 5 $\mathrm{cm}$ below the moss surface were measured simultaneously with the $\mathrm{CO}_{2}$ exchange measurements to relate the fluxes to the prevailing environmental conditions. NEE and RE were calculated as the linear change in $\mathrm{CO}_{2}$ concentration as a function of time by fitting a linear regression line.

\subsection{Statistical Analyses}

Since we had a limited amount of data on the $\mathrm{CO}_{2}$ exchange, we could not reliably model fluxes on which to base simulations of seasonal estimates of NEE and RE. Instead, we concentrated on testing the significance of the effect of microtopographic habitat on instantaneous NEE and RE, and interpolating the seasonal mean carbon balances for both microtopographical habitats over the growing seasons. Since observations were made on the same measurement plots over a period of time (four growing seasons 2010-2013), the observed responses were therefore correlated. As opposed to two-way ANOVA, linear mixed models have been designed to handle correlated data with unequal variances from normal distributions [25]. Thus, the analyses of instantaneous flux rates were based on fixed effects models with restricted maximum likelihood estimation method using the linear mixed procedure in SPSS Statistics ver. 22 (IBM Corp., USA). Test results were considered significant when $p<0.05$.

\section{Results}

\subsection{Environmental Conditions during the Study Period}

The thermal growing season started in late April or early May and lasted until the end of October during study 
years 2010-2013 (Figure 1). The mean seasonal (April-October) temperatures at Kauhaneva were slightly higher in all study years 2010-2013 except 2012 than the long term average of 1984-2014 (10.5, 11.4, 9.4, 10.6 and $9.7^{\circ} \mathrm{C}$, respectively) (Figure 1). However, the monthly temperatures of early season (April-July) in 2010 and 2011 were clearly higher than the long term average of 1984-2014 (Figure 1). Peat temperatures at $5 \mathrm{~cm}$ below the moss surface measured simultaneously with the $\mathrm{CO}_{2}$ exchange measurements were typically close to $0^{\circ} \mathrm{C}$ during the first measurements after snowmelt and rose to their seasonal maximum in July at ca. $+20^{\circ} \mathrm{C}$ (Figure 2). Peat temperatures in hummocks were generally slightly higher than in lawns (Figure 2). The highest photosynthetically active radiations (PAR) under the chamber roof measured simultaneously with the $\mathrm{CO}_{2}$ exchange measurements varied from ca. $200 \mu \mathrm{mol} \cdot \mathrm{m}^{-2} \cdot \mathrm{s}^{-1}$ during late season in October to $1600 \mu \mathrm{mol} \cdot \mathrm{m}^{-2} \cdot \mathrm{s}^{-1}$ during peak season in July (Figure 3). Oppositely, measured PAR values were during early season in April only ca. $20 \%$ lower than during peak season in July (Figure 3).

The timing of snowmelt varied rather slightly during the study period, occurring early April in all study years except 2012. Although the season of 2012 was the coldest during our study period 2010-2013, the snowmelt was, however, the earliest taking place in the middle of March in 2012. Short-term (ca. one month) inundation occurred immediately after snowmelt especially in spring 2010 on the lawn plots (Figure 2). The snow and/or inundation free period lasted for seven months covering the whole growing season for the hummocks, whereas only ca. six months for the lawns having the inundation after the snowmelt and delayed snowmelt compared to hummocks. In 2012, the difference between hummocks and lawns in the snow and/or inundation free period was almost one and a half months.

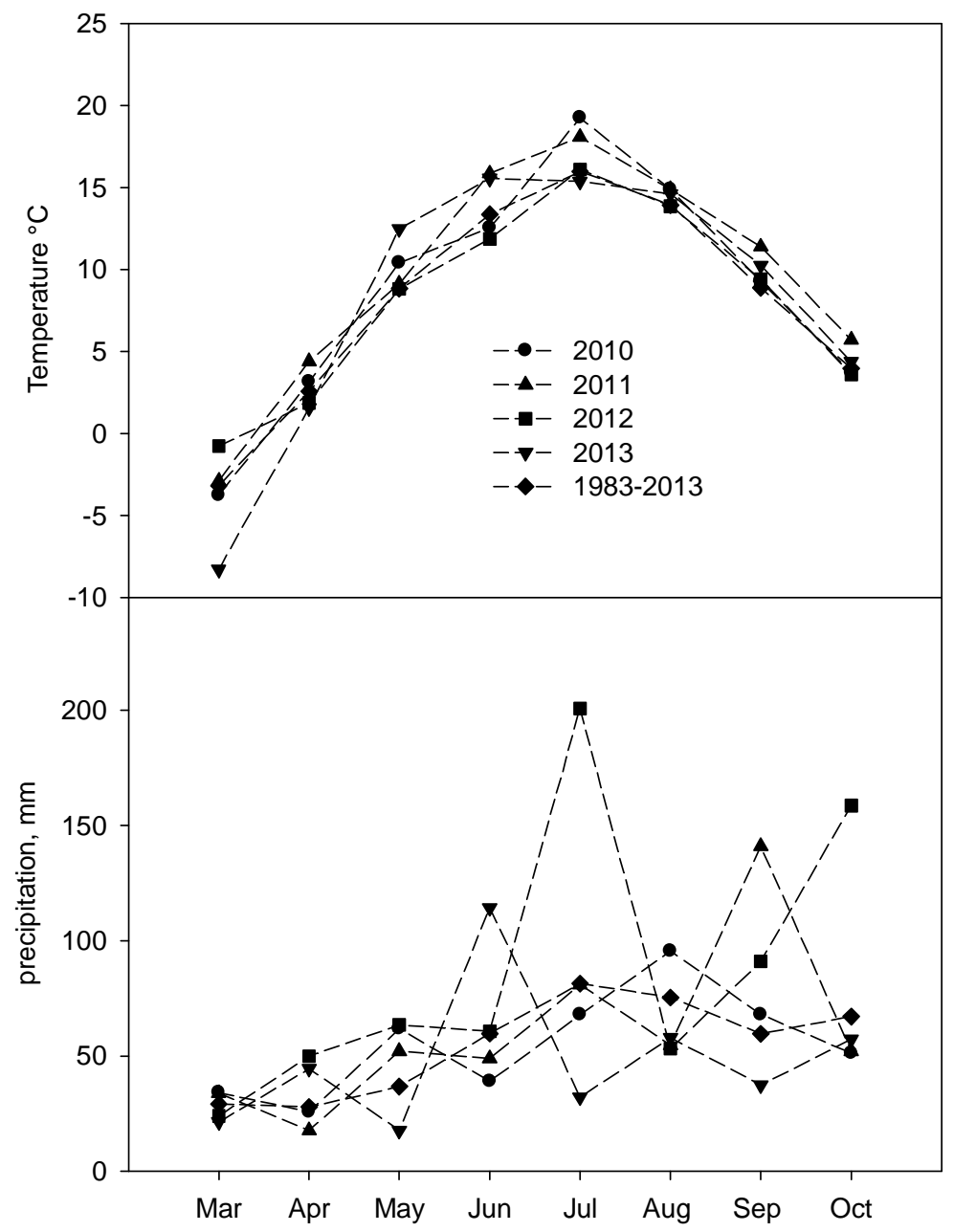

Figure 1. Mean air temperature and monthly precipitation at Kauhaneva from March to October during 2010-2013 and as 30-year average 1983-2013. 


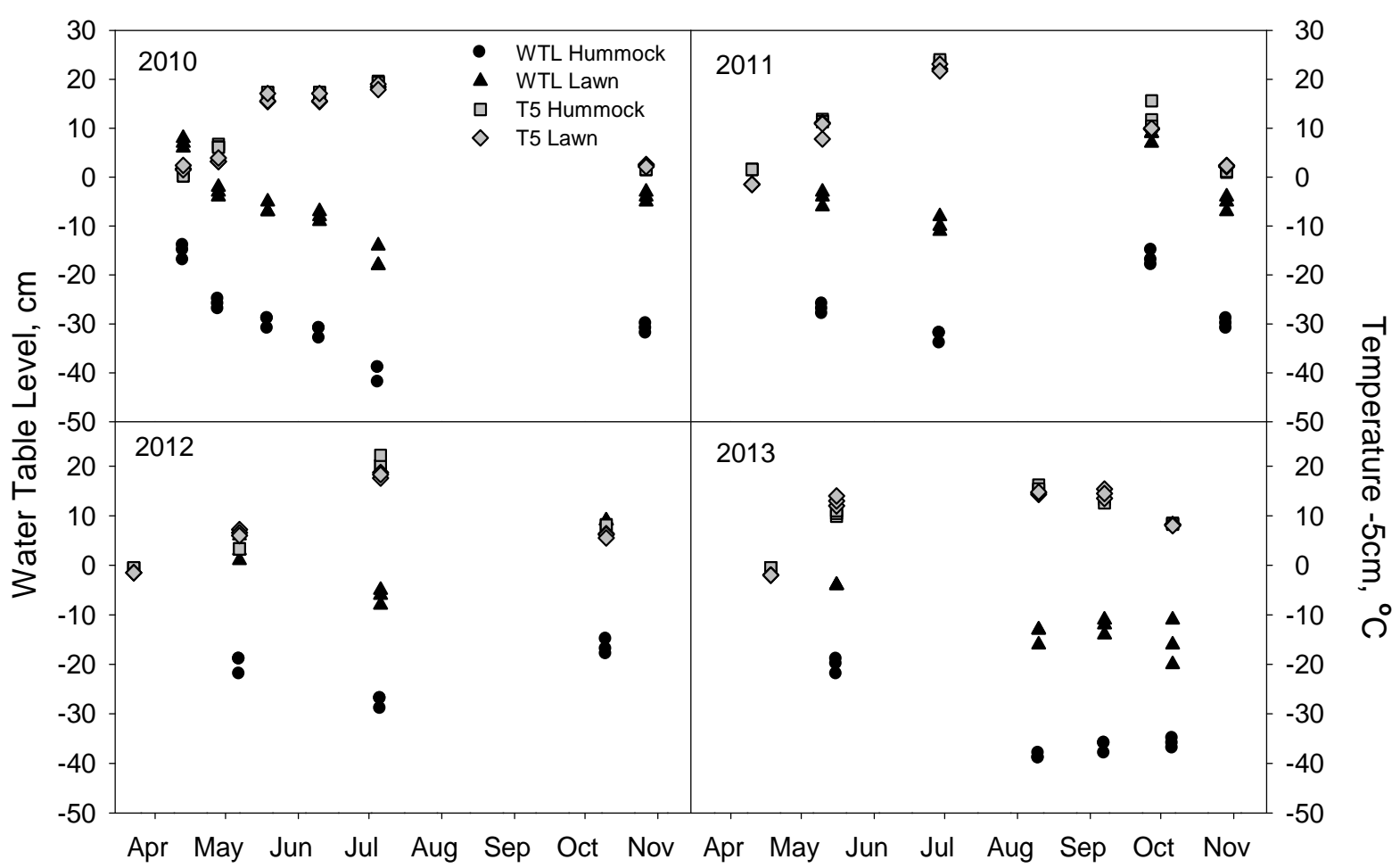

Figure 2. Measured water table level (WTL) and soil temperature (T5) values at $5 \mathrm{~cm}$ depth below soil surface at Kauhaneva during 2010-2013. WTL and T5 values based on manual measurements made in conjunction with $\mathrm{CO}_{2}$ exchange measurements. Three WTL measurements from March-April 2011-2013 are missing because of the solid soil frost.

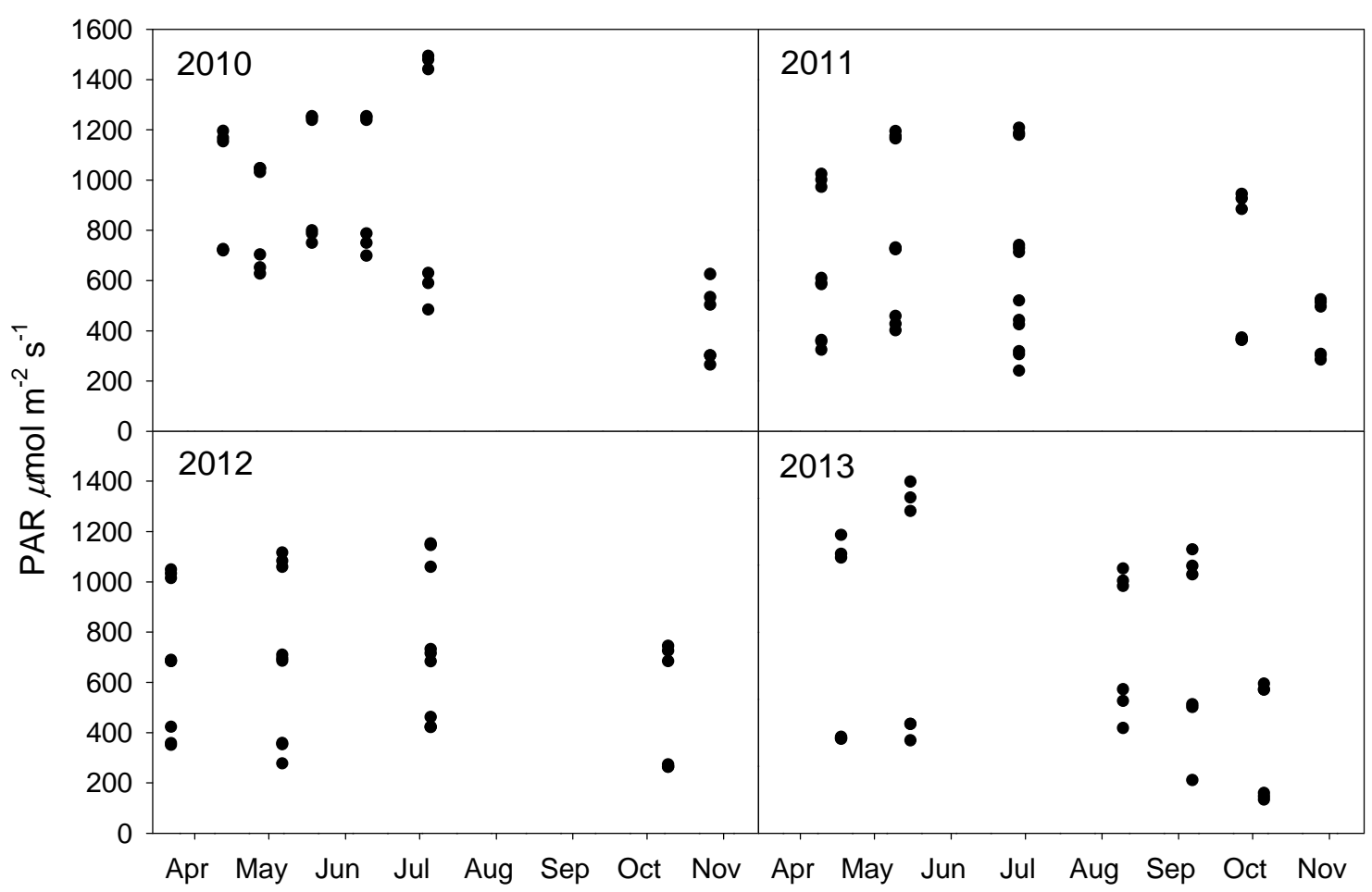

Figure 3. Measured photosynthetically active radiations (PAR) at Kauhaneva during 2010-2013. PAR values are based on manual measurements made in conjunction with $\mathrm{CO}_{2}$ exchange measurements. Part of the measurements was done under an artificial shade reducing the ambient light by $40 \%-60 \%$ resulting the rather large variation in PARs. 
The cumulative precipitations during April-October were rather close to the long-term average of 1984-2014 (408 mm) in all study years 2010-2013 except in 2012 (678 mm) (Figure 1). Especially the monthly precipitations in July and October 2012 were clearly higher than the monthly long term averages of 1984-2014 (Figure 1). Water table levels (WTL) measured in a perforated tube next to each $\mathrm{CO}_{2}$ exchange measurement plot varied from ca. $-10 \mathrm{~cm}$ to $-40 \mathrm{~cm}$ below the soil surface for hummocks, and from ca. $+10 \mathrm{~cm}$ above the soil surface (inundation) in spring to $-15 \mathrm{~cm}$ below the soil surface for lawns (Figure 2). In early spring also solid soil frost occurred during the first $\mathrm{CO}_{2}$ exchange measurement occasions in 2011-2013, and therefore WTLs cannot be measured (Figure 2).

The maximum leaf area index (LAI) of vascular plants was generally very low at Kauhaneva, in average ca. $0.14 \mathrm{~m}^{2} \cdot \mathrm{m}^{-2}$ for hummocks and ca. $0.17 \mathrm{~m}^{2} \cdot \mathrm{m}^{-2}$ for lawns, respectively. The variation in LAIs was very small between the study years and the plots. Dominant vascular plants on the hummocks were Empetrum nigrum, Andromeda polifolia and Rubus chamaemorus, on the lawns Eriophorum vaginatum, Andromeda polifolia and Vaccinium oxycoccos, respectively.

\section{2. $\mathrm{CO}_{2}$ Exchange}

The mean measured seasonal NEE of hummocks during 2010-2013 was 329, 218, 201 and $162 \mathrm{mg} \mathrm{CO}_{2} \mathrm{~m}^{-2} \cdot \mathrm{h}^{-1}$, respectively, and for lawns 220, 182, 240 and $156 \mathrm{mg} \mathrm{CO} \mathrm{m}^{-2} \cdot \mathrm{h}^{-1}$, respectively (Figure 4). All mean seasonal NEE values showed a positive seasonal net balance, i.e. all measured $\mathrm{CO}_{2}$ exchange plots acted as a sink for $\mathrm{CO}_{2}$ during 2010-2013, but both microtopographical habitats showed relatively large differences in NEE between the years (Figure 4). The mean measured seasonal NEE of hummocks was higher than the NEE of lawns in every year during 2010-2013, except in 2012 (Figure 4). However, the difference between the NEE of hummocks and lawns was statistically significant only in 2010 (Table 1). Assuming that the growing season at Kauhaneva over the four-year study period 2010-2013 is considered to last ca. seven months for hummocks and ca. six months for lawns, the seasonal carbon balance was $310 \mathrm{~g} \mathrm{CO}_{2}-\mathrm{C} \mathrm{m}^{-2}$ for hummocks and $233 \mathrm{~g} \mathrm{CO}_{2}-\mathrm{C}$ $\mathrm{m}^{-2}$ for lawns, respectively.

The mean measured seasonal RE in the dark for hummocks during 2010-2013 was 723, 537, 402 and $566 \mathrm{mg}$ $\mathrm{CO}_{2} \mathrm{~m}^{-2} \cdot \mathrm{h}^{-1}$, respectively, and for lawns 417, 259, 282 and $270 \mathrm{mg} \mathrm{CO} \mathrm{m}^{-2} \cdot \mathrm{h}^{-1}$, respectively (Figure 4). The mean measured seasonal RE of hummocks was clearly higher than the RE of lawns in every year during 2010-2013 (Figure 4). The difference between the RE of hummocks and lawns was significant in every year during 2010-2013 (Table 1).

\section{Discussion}

In our four-year study the inter-annual variability in climatic conditions was considerable and partly unexpected as reported in other multi-year studies (e.g. [26]) as well. For instance, during the study period there was a very warm growing season in 2010, but a cold season in 2012 too. Additionally, although the season of 2012 was the coldest during our study period 2010-2013, the snowmelt was, however, the earliest occurring already in the middle of March.

In general, instantaneous NEE and RE in our study roughly corresponded to those measured in other studies on pristine mires [26]-[29]. Likewise to the above studies, annual variation in NEE and RE results was considerable in our study, highlighting the importance of multi-year empirical studies. The mean measured seasonal NEE, i.e. the net carbon sequestration, of hummocks during 2010-2013 was generally slightly higher than the NEE of lawns, but the differences between the NEE of microtopographical habitats were rather small and not significant, except in 2010. However, the mean measured seasonal RE of hummocks was clearly higher than the RE of lawns in every year during 2010-2013, and the difference between the RE of hummocks and lawns was significant in every year during 2010-2013. A reason for the more significant differences in RE than NEE, may be the higher sensitivity of RE on alterations in WTL, in particular during early spring and late autumn when the differences in WTL between hummocks and lawns were at greatest. Also Riutta et al. [26] and Ballantyne et al. [30] reported the significantly increased RE with lowered WTL on boreal poor fens.

The other important reason for the observed higher seasonal carbon sequestration of hummocks than that of lawns besides the slightly higher rate of carbon accumulation was the longer snow- and inundation-free period on hummocks, i.e. the duration of physiologically active growing season. There is strong evidence that the interannual variation of the carbon sequestration on boreal mires originates from the variations in the snow-free 


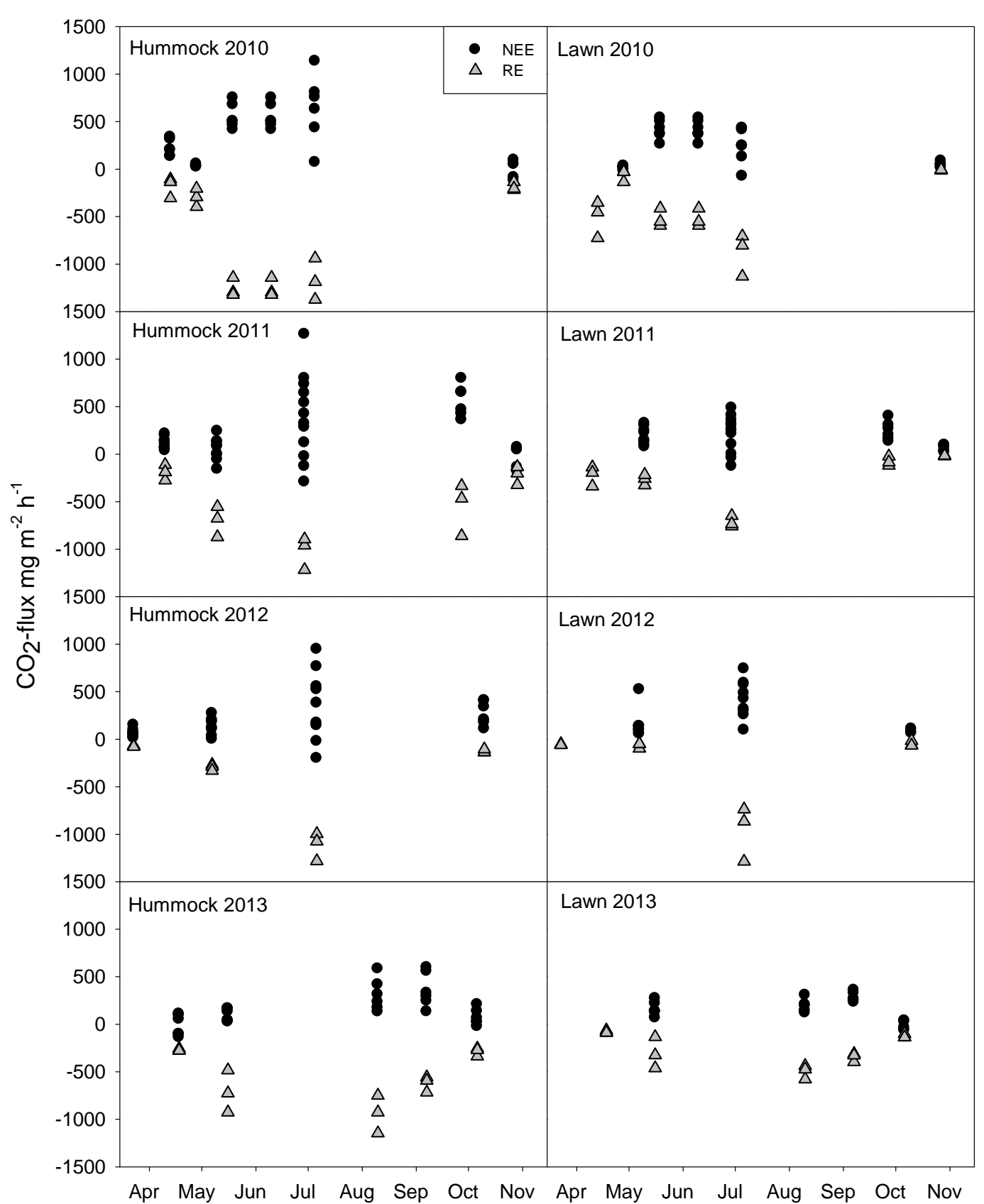

Figure 4. Measured instantaneous $\mathrm{CO}_{2}$ exchange (NEE and RE) of the microtopographical habitats (hummocks and lawns) during 2010-2013.

Table 1. The significances (F- and their $p$-values) of differences between the NEE/RE of the hummocks and lawns (microform effect) during 2010-2013. Test results were considered significant when $p<0.05$, and marked by the asterisk.

\begin{tabular}{ccccc}
\hline Microform effect & 2010 & 2011 & 2012 & 2013 \\
\hline NEE & $\mathrm{F}=5.24 ; p<0.05^{*}$ & $\mathrm{~F}=0.42 ; p=0.522$ & $\mathrm{~F}=1.88 ; p=0.177$ & $\mathrm{~F}=1.70 ; p=0.199$ \\
$\mathrm{RE}$ & $\mathrm{F}=9.91 ; p<0.05^{*}$ & $\mathrm{~F}=18.28 ; p<0.05^{*}$ & $\mathrm{~F}=10.62 ; p<0.05^{*}$ & $\mathrm{~F}=38.39 ; p<0.05^{*}$ \\
\hline
\end{tabular}

period [18] or from the variations in the inundation [21]. Our study shows that longer snow-free period due to early snowmelt enhances more the carbon sequestration of microtopographically higher habitats (hummocks) 
than the surroundings (lawns). This is mainly because of snow cover and too high WTL (inundation) for the effective carbon sequestration in early spring on the microtopographically lower lawns.

In our study, the photosynthesis of mire vegetation did not occur under snow cover or under inundation, although the photosynthetic activity of boreal dwarf shrubs under snow cover has shown to take place [31] [32]. At Kauhaneva, the LAI of vascular plants was very low, and the major part of photosynthetic activity was due to Sphagnum mosses that are not likely capable for photosynthesis under snow. However, Sphagnum mosses have the ability to grow under lower solar irradiance and temperature conditions than the vascular plants [19] [20]. Accordingly, Sphagnum mosses grow in low temperature conditions immediately after snowmelt and/or after the removal of inundation in early spring, or in low solar irradiance conditions in late autumn. Since the increase of greenhouse gases in the atmosphere is expected to instigate warming in high northern latitudes especially during winter and early spring [33]-[35], the snowmelt will take place earlier in the future, and this will probably prolong the effective growing season especially during early spring in rather high solar irradiance conditions [36] [37]. The ability of plants to benefit from intermittent warm periods during winter and early spring, without succumbing to freezing damage during subsequent periods of frost, depends on a delicate balance between activity and protection, which may easily tip over in conditions where the annual winter- and springtime temperatures are rising [31] [32]. Plants having a capability for the effective winter- and springtime photosynthesis, like Sphagnum mosses, may significantly benefit from increased wintertime temperatures and earlier snowmelt.

Sphagnum mosses are known as a mire plant group that is the most sensitive to environmental conditions, especially to soil moisture, as a result of an optimum WTL close to the surface and narrowest tolerance to WTL variation [26] [38] [39]. Furthermore, unfavorable environmental conditions may diminish directly the amount of phytomass, i.e. in terms of the abundance and coverage, of a certain Sphagnum group [26]. Also our study demonstrated that microtopographically scattered, functional plant groups on a bog differed in their responses to snow cover and WTL and, consequently, changes in snow cover and WTL may modify their contribution to the ecosystem $\mathrm{CO}_{2}$ dynamics in the future. In particular, the hummock-forming Sphagnum mosses that exposed firstly from snow cover showed to gain additional time for photosynthesis and thus further benefit compared to other mire plants. This may further enhance the expansion of hummock-forming Sphagnum moss dominating the raised bogs towards northern aapa-mire region due to the global warming. Since Sphagnum is one of the main peat forming and carbon accumulating plant genus globally, the large-scale shifting from lawn-forming Sphagnum mosses towards hummock-forming Sphagnum mosses in northern boreal region may play a significant role in the global carbon balance. The results of this study are therefore of general interest for assessing the annual photosynthetic cycle of this abundant mire plant genus throughout the boreal zone, emphasizing the role of early growing season.

\section{References}

[1] Gorham, E. (1991) Northern Peatlands: Role in the Carbon Cycle and Probable Responses to Climatic Warming. Ecological Applications, 1, 182-195. http://dx.doi.org/10.2307/1941811

[2] Franzen, L.G. (1994) Are Wetlands the Key to the Ice-Age Cycle Enigma? Ambio, 23, 300-308.

[3] Clymo, R.S. and Hayward, P.M. (1982) The Ecology of Sphagnum. In: Smith, A.J.E., Ed., Bryophyte Ecology, Chapman \& Hall, New York, 229-289. http://dx.doi.org/10.1007/978-94-009-5891-3 8

[4] Shaw, A.J. (2000) Phylogeny of the Sphagnopsida Based on Chloroplast and Nuclear DNA Sequences. Bryologist, 103, 277-306. http://dx.doi.org/10.1639/0007-2745(2000)103[0277:POTSBO]2.0.CO;2

[5] Gunnarsson, U. (2005) Global Patterns of Sphagnum Productivity. Journal of Bryology, 27, 269-279. http://dx.doi.org/10.1179/174328205X70029

[6] Houghton, J.T., Ding, Y. and Griggs, D.J. (2001) Climate Change 2001: The Scientific Basis Contribution of Working Group I to the Third Assessment Report of the Intergovernmental Panel on Climate Change. Cambridge University Press, Cambridge.

[7] Clymo, R.S., Turunen, J. and Tolonen, K. (1998) Carbon Accumulation in Peatland. Oikos, 81, 368-388. http://dx.doi.org/10.2307/3547057

[8] Dorrepaal, E., Aerts, R., Cornelissen, J.H.C., Callaghan, T.V. and van Logtestijn, R.S.P. (2003) Summer Warming and Increased Winter Snow Cover Affect Sphagnum fuscum Growth, Structure and Production in a Sub-Arctic Bog. Global Change Biology, 10, 93-104. http://dx.doi.org/10.1111/j.1365-2486.2003.00718.x

[9] Malmer, N., Svensson, B.M. and Wallen, B. (1994) Interactions between Sphagnum Mosses and Field Layer Vascular 
Plants in the Development of Peat-Forming Systems. Folia Geobotanica \& Phytotaxonomica, 29, 483-496. http://dx.doi.org/10.1007/BF02883146

[10] Rydin, H. (1997) Competition among Bryophytes. Advances in Bryology, 6, 135-168.

[11] Sonesson, M., Carlsson, B.Å., Callaghan, T.V., Halling, S., Björn, L.O., Bertgren, M. and Johanson, U. (2002) Growth of Two Peat-Forming Mosses in Subarctic Mires: Species Interactions and Effects of Simulated Climate Change. Oikos, 99, 151-160. http://dx.doi.org/10.1034/j.1600-0706.2002.990115.x

[12] Dorrepaal, E., Aerts, R., Cornelissen, J.H.C., van Logtestijn, R.S.P. and Callaghan, T.V. (2006) Sphagnum Modifies Climate-Change Impacts on Subarctic Vascular Bog Plants. Functional Ecology, 20, 31-41. http://dx.doi.org/10.1111/j.1365-2435.2006.01076.x

[13] Lee, J.A. and Woodin, S.J. (1988) Vegetation Structure and the Interception of Acid Deposition by Ombrotrophic Mires. In: Verhoeven, J.T.A., Heil, G.W. and Werger, M.J.A., Eds., Vegetation Structure in Relation to Carbon and Nutrient Economy, Academic Publishing, The Hague, 137-147.

[14] Van Breemen, N. (1995) How Sphagnum Bogs Down Other Plants. Trends in Ecology and Evolution, 10, $270-275$. http://dx.doi.org/10.1016/0169-5347(95)90007-1

[15] Li, Y.H. and Vitt, D.H. (1997) Patterns of Retention and Utilization of Aerially Deposited Nitrogen in Boreal Peatlands. Ecoscience, 4, 106-116.

[16] Backéus, I. (1985) Aboveground Production and Growth Dynamics of Vascular Bog Plants in Central Sweden. Acta Phytogeographica Suecica, 74, 1-98.

[17] Moore, P.D. (2002) The Future of Cool Temperate Bogs. Environmental Conservation, 29, 3-20. http://dx.doi.org/10.1017/s0376892902000024

[18] Aurela, M., Laurila, T. and Tuovinen, J.-P. (2004) The Timing of Snowmelt Controls the Annual $\mathrm{CO}_{2}$ Balance in a Subarctic Fen. Geophysical Research Letters, 31, Article ID: L16119. http://dx.doi.org/10.1029/2004GL020315

[19] Harley, P.C., Tenhunen, J.D., Murray, K.J. and Beyers, J. (1989) Irradiance and Temperature Effects on Photosynthesis of Tussock Tundra Sphagnum Mosses from the Foothills of the Philip Smith Mountains, Alaska. Oecologia, 79, 251259. http://dx.doi.org/10.1007/BF00388485

[20] Balagurova, N., Drosdov, S. and Grabovik, S. (1996) Cold and Heat Resistance of Five Species of Sphagnum. Annales Botanici Fennici, 33, 33-37.

[21] Robroek, B.J.M., Limpens, J., Breeuwer, A. and Schouten, M.G.C. (2007) Effects of Water Level and Temperature on Performance of Four Sphagnum Mosses. Plant Ecology, 190, 97-107. http://dx.doi.org/10.1007/s11258-006-9193-5

[22] Laine, J., Vasander, H., Hotanen, J.-P., Nousiainen, H., Saarinen, M. and Penttilä, T. (2012) Suotyypit ja turvekankaat -Opas kasvupaikkojen tunnistamiseen. Metsäkustannus, 160 p. (In Finnish)

[23] Wilson, D., Alm, J., Riutta, T., Laine, J., Byrne, K.A., Farrel, E.P. and Tuittila, E.-S. (2007) A High Resolution Green Area Index for Modelling the Seasonal Dynamics of $\mathrm{CO}_{2}$ Exchange in Peatland. Plant Ecology, 190, 37-51. http://dx.doi.org/10.1007/s11258-006-9189-1

[24] Alm, J., Shurpali, N.J., Tuittila, E.-S., Laurila, T., Maljanen, M., Saarnio, S. and Minkkinen, K. (2007) Methods for Determining Emission Factors for the Use of Peat and Peatlands-Flux Measurements and Modeling. Boreal Environment Research, 12, 85-100.

[25] Pan, W. and Connett, J.E. (2002) Selecting the Working Correlation Structure in Generalized Estimating Equations with Application to the Lung Health Study. Statistica Sinica, 12, 475-490.

[26] Riutta, T., Laine, J. and Tuittila, E.-S. (2007) Sensitivity of $\mathrm{CO}_{2}$ Exchange of Fen Ecosystem Components to Water Level Variation. Ecosystems, 10, 718-733. http://dx.doi.org/10.1007/s10021-007-9046-7

[27] Frolking, S., Roulet, N., Moore, T., Lafleur, P., Bubier, J. and Crill, P. (2002) Modeling Seasonal to Annual Carbon Balance of Mer Bleue Bog, Ontario, Canada. Global Biogeochemical Cycles, 16, 1-21. http://dx.doi.org/10.1029/2001GB001457

[28] Aurela, M., Lohila, A., Tuovinen, J.-P., Hatakka, J., Riutta, T. and Laurila, T. (2009) Carbon Dioxide Exchange on a Northern Boreal Fen. Boreal Environment Research, 14, 699-710.

[29] Chivers, M.R., Turetsky, M.R., Waddington, J.M., Harden, J.W. and McGuire, A.D. (2009) Effects of Experimental Water Table and Temperature Manipulations on Ecosystem $\mathrm{CO}_{2}$ Fluxes in an Alaskan Rich Fen. Ecosystems, 12, 1329. 1342 .

[30] Ballantyne, D.M., Hribljan, J.A., Pypker, T.B. and Chimner, R.A. (2013) Long-Term Water Table Manipulations Alter Peatland Gaseous Carbon Fluxes in Northern Michican. Wetlands Ecology and Management, 22, 35-47. http://dx.doi.org/10.1007/s11273-013-9320-8

[31] Starr, G. and Oberbauer, S.F. (2003) Photosynthesis of Arctic Evergreens under Snow: Implications for Tundra Ecosystem Carbon Balance. Ecology, 84, 1415-1420. http://dx.doi.org/10.1890/02-3154 
[32] Lundell, R., Saarinen, T., Åström, H. and Hänninen, H. (2008) The Boreal Dwarf Shrub Vaccinium vitis-idaea Retains Its Capacity for Photosynthesis through the Winter. Botany, 86, 491-500. http://dx.doi.org/10.1139/B08-022

[33] Kattenberg, A., Giorgi, F., Grassl, H., Meehl, G.A., Mitchell, J.F.B., Stouffer, R.J., Tokioka, T., Weaver, A.J. and Wigley, T.M.L. (1996) Climate Models_-Projections of Future Climate. In: Houghton, J.T., Filho, L.G.M., Callander, B.A., Harris, N., Kattenberg, A. and Maskell, K., Eds., Climate Change 1995: The Science of Climate Change, Cambridge University Press, Cambridge, 285-357.

[34] IPCC (2007) Climate Change 2007. Fourth Assessment Report. Intergovernmental Panel on Climate Change, Cambridge University Press, Cambridge.

[35] Moss, R.H., Edmonds, J.A., Hibbard, K.A., Manning, M.R., Rose, S.K., van Vuuren, D.P., Carter, T.R., Emori, S., Kainuma, M., Kram, T., Meehl, G.A., Mitchell, J.F.B., Nakicenovic, N., Riahi, K., Smith, S.J., Stouffer, R.J., Thomson, A.M., Weyant, J.P. and Wilbanks, T.J. (2010) The Next Generation of Scenarios for Climate Change Research and Assessment. Nature, 463, 747-756. http://dx.doi.org/10.1038/nature08823

[36] Walther, G.-R., Post, E., Convey, P., Menzel, A., Parmesan, C., Beebee, T.C.J., Fromentin, J.-M., Hoegh-Guldberg, O. and Bairlein, F. (2002) Ecological Responses to Recent Climate Change. Nature, 416, 389-395. http://dx.doi.org/10.1038/416389a

[37] Räisänen, J., Hansson, U., Ullerstig, A., Döscher, R., Graham, L.P., Jones, C., Meier, M., Samuelsson, P. and Willen, U. (2003) GCM Driven Simulations of Recent and Future Climate with the Rossby Centre Coupled AtmosphereBaltic Sea Regional Climate Model RCAO. Reports Meteorology and Climatology, SMHI, Norrköping, 1-61.

[38] Silvola, J. and Aaltonen, H. (1984) Water Content and Photosynthesis in the Peat Mosses Sphagnum fuscum and Sphagnum angustifolium. Annales Botanici Fennici, 21, 1-6.

[39] Schipperges, B. and Rydin, H. (1998) Response of Photosynthesis of Sphagnum Species from Contrasting Microhabitats to Tissue Water Content and Repeated Desiccation. New Phytologist, 140, 677-684.

http://dx.doi.org/10.1046/j.1469-8137.1998.00311.x 